\title{
The Relationships of Type A Behaviour, Organisational and Personality Variables among Pharmacists and Accountants - A Further Analysis
}

$R$ van Wyk and AB Boshoff

Department of Business Management, University of Pretoria

\begin{abstract}
This paper is a follow-up of a previous study on the correlates of Type A Behaviour among professional workers in South Africa. In the previous study, data were analysed for a joint group of 375 pharmacists and accountants. In the present study, the two professions are analysed separately. Product-Moment Correlation and Stepwise Multiple Regression Analysis are used to determine the relationships between Job Satisfaction, Job Involvement, a number of personality variables and Type $A$ Behaviour in samples of accountants $(N=$ 175) and pharmacists $(N=200)$. Differences between the results for the two occupations were found to exist and are discussed in this paper.
\end{abstract}

JEL J20

\section{INTRODUCTION}

The two groups of participants, accountants and pharmacists, included in the current study, can be seen as different professional cultural groups. The statement is forwarded that a professional cultural milieu is developed in each of the two professions. Anastasi (1990) warns that cultural differences may affect the responses to particular psychometric instruments due to group differences, thus reducing the validity of measuring instruments for specific groups. Members of the two professions analysed here have widely different work milieus which may also lead to different cultural milieus. In terms of Holland's (1985) classification of occupations, pharmacists and accountants may be seen as belonging to two separate career categories with personality types that are mutually exclusive. Pharmacists are found in the Holland (1985) categories of highly investigative, moderately artistic and weakly realistic. The accountant profession falls in the categories of remarkably conventional, somewhat enterprising and vaguely social individuals. 
In the previous study, referred to as Van Wyk et al. (1999a), some personality and organisational variables were related to Type $A$ Behaviour scores when the responses of pharmacists $(\mathrm{N}=200)$ and accountants $(\mathrm{N}=175)$ were combined. In the present analysis the two groups are treated as separate subsets and the relationship between Type A Behaviour and personality and organisational variables investigated.

The high demands that westernised urban societies make on workers, professionals in particular, may well lead to high levels of stress. Such a degree of stress may be the antecedent to Type A Behaviour, or lead to certain outcomes resulting from this behaviour pattem (Byme, 1987). Further investigation of possible antecedents of Type A Behaviour therefore seems warranted. A discussion on the origin of Type A Behaviour and the relationship with variables investigated in various studies is available in Van Wyk et al. (1999a).

\section{METHOD}

\section{Sample}

The present sample consists of 375 professionals from two occupations, namely, pharmacists $(\mathrm{N}=200)$ and accountants $(\mathrm{N}=175)$. The total sample had a mean age of 41.6 years (Range: $22-84 ; \mathrm{SD}=12.46$ ). The mean ages of the subsamples were: pharmacists 39.46 years; (Range $=22-84 ; \mathrm{SD}=12.70$ ) and accountants 44.05 years (Range $=24-82$ years; $S D=11.95$ ). Of the total sample, males formed $58.9 \%(\mathrm{~N}=221)$ and females $41.1 \%(\mathrm{~N}=154)$. The males consisted of pharmacists $(\mathrm{N}=68,30.8 \%)$ and accountants $(\mathrm{N}=153$, $69.2 \%$ ). The females consisted of pharmacists $(\mathrm{N}=132,85.7 \%)$ and accountants $(\mathrm{N}=22,14.3 \%)$.

The home languages of the participants were given as: English $(\mathrm{N}=211$, $56,3 \%)$, Afrikaans $(\mathrm{N}=158,42.1 \%)$, Venda $(\mathrm{N}=1,0.3 \%), \mathrm{Zulu}(\mathrm{N}=2,0.5 \%)$, North Sotho $(\mathrm{N}=2,0.5 \%)$. The home language of one participant was unknown. The home languages of the pharmacists were: English $(\mathrm{N}=105$, $52.5 \%$ ), Afrikaans $(\mathrm{N}=90,45.0 \%)$, Venda $(\mathrm{N}=1,0.5 \%)$, Zulu $(\mathrm{N}=1,0.5 \%$ ), North Sotho $(\mathrm{N}=2,1.0 \%)$ and unknown $(0.5 \%)$. The home languages of accountants were: English $(\mathrm{N}=106,60.6 \%)$, Afrikaans $(\mathrm{N}=68,38.9 \%)$, Zulu $(\mathrm{N}=1,0.6 \%)$.

Of the total sample of 375 participants, $201(53.6 \%)$ identified themselves as employees of organisations, $169(45.1 \%)$ saw themselves as private practitioners and $5(1.3 \%)$ did not provide information in this respect. Of pharmacists, 46 
(23\%) were in private practice and $153(76.5 \%)$ worked as employees. One pharmacist $(0.5 \%)$ did not provide information in this respect. The responses of accountants indicated that $123(70.3 \%)$ were in private practice and $48(27.40 \%)$ worked as employees. Four $(2.3 \%)$ of the accountants did not provide information in this respect.

The number of jobs occupied by participants prior to the study varied between one and eight. The majority of participants $(93 \%)$ had held fewer than five jobs prior to the study, with pharmacists (mean $=2.73, \mathrm{SD}=1.54$ ) having had numerically fewer jobs than accountants (mean $=3.18, \mathrm{SD}=1.47$ ). The number of years worked until the time of the study varied between 1 and 60 for the total sample. Pharmacists worked between 1 and 58 years and accountants between 1 and 60 years. Members of the total sample had worked a mean number of 18.7 years $(S D=12.56)$, pharmacists a mean of 15.3 years $(S D=12.04)$ and accountants a mean of 21.3 years $(S D=12.39$ ). The average number of organisations worked for prior to the study by the total sample was 2.83 (SD = 1.56). The corresponding figures for the two groups were pharmacists 2.73 (SD $=1.51)$ and accountants $2.95(\mathrm{SD}=1.62)$.

The marital status of the total sample of participants who provided information were: married $\mathrm{N}=295(78.7 \%)$, single $\mathrm{N}=62(16.5 \%)$ divorced $\mathrm{N}=10(2.7 \%)$, widowed $N=6(1.6 \%)$ and cohabiting $N=2(0.5 \%)$. The marital status of the two occupational groups were: pharmacists: married $\mathrm{N}=148(74 \%)$, single $\mathrm{N}=$ $41(20.5 \%)$, divorced $\mathrm{N}=8(4.0 \%)$, widowed $\mathrm{N}=1(0.5 \%)$ and cohabiting $\mathrm{N}=$ $2(1.0 \%)$; accountants: married $\mathrm{N}=147(84 \%)$, single $\mathrm{N}=21(12 \%)$, divorced $\mathrm{N}$ $=2(1.1 \%)$ and widowed $\mathrm{N}=5(2.9 \%)$. The majority of the participants $(\mathrm{N}=$ $289,77 \%$ ) indicated that they grew up in an urban environment (pharmacists $\mathrm{N}$ $=150,75 \%$ and accountants $N=139,79.4 \%$ ). The Gauteng Province of South Africa is indicated as the region in which most of the participants $(\mathrm{N}=213$, $57 \%$ ) grew up (pharmacists $\mathrm{N}=113,56.5 \%$ and accountants $\mathrm{N}=101,57.7 \%$ ), with a more or less even distribution over the other eight provinces.

\section{Procedure}

Details conceming the procedure followed are found in Van Wyk et al. (1999a).

\section{RESULTS}

Statistical analyses were done to determine the possible relationships between Type A Behaviour, as shown by the pharmacists and accountants, and the different variables measured in the study. The factor scales identified for each instrument (Van Wyk et al. (1999b) are listed in Table 1. 


\section{Table 1 List of Identified Factors for each Instrument}

\begin{tabular}{|l|l|l|}
\hline JF1 & Jenkins Factor 1 & Achievement \\
\hline JF2 & Jenkins Factor 2 & Hard Driving/Competitive \\
\hline JF3 & Jenkins Factor 3 & Speed and Impatience \\
\hline JFG & Jenkins G & Jenkins Global \\
\hline LC1 & Locus of Control 1 & Internal \\
\hline LC2 & Locus of Control 2 & External \\
\hline LC3 & Locus of Control 3 & Vicissitudes of Life \\
\hline CO1 & Career Orientations 1 & Service Dedication \\
\hline CO2 & Career Orientations 2 & Job Security \\
\hline CO3 & Career Orientations 3 & Entrepreneurial \\
\hline CO4 & Career Orientations 4 & Life Style Integration \\
\hline J1 & Job Involvement & \\
\hline JS1 & Job Satisfaction 1 & General \\
\hline JS2 & Job Satisfaction 2 & Intrinsic \\
\hline JS3 & Job Satisfaction 3 & Supervision \\
\hline SC1 & Self-Concept 1 & Power \\
\hline SC2 & Self-Concept 2 & Task Accomplishment/Moral \\
\hline SC3 & Self-Concept 3 & Likeability \\
\hline ENT1 & Entrepreneurial Attitude 1 & Economic Innovation \\
\hline ENT2 & Entrepreneurial Attitude 2 & Achievement/Personal Control \\
\hline ENT3 & Entrepreneurial Attitude 3 & Self-Esteem \\
\hline
\end{tabular}

The intercorrelations among the scores on the factor scales for the two professions were measured. Due to the very extensive results and the shortage of space, these statistics are not reproduced here but available from the firstmentioned author on request.

Stepwise Multiple Regression was used to construct multivariate models of the relationships between the different personality and organisational variables and the level of Type A Behaviour. Separate models were built for pharmacists and for accountants. The global scores on the Jenkins instrument and the Type A sub-scale scores served as dependent variables. The results are shown in Tables 2 to 5 . In these tables the independent (predictor) variables are shown in the order in which they entered into the Multiple Regression Model with the different Jenkins Type A variables as dependent variables. 
Table 2 Results of Stepwise Multiple Regression Analysis of Sub-Scale scores on Jenkins Activity Survey Scores as Dependent Variable for Pharmacists

Dependent Variable: Jenkins Global Score (Pharmacists $N=200$ )

\begin{tabular}{|l|c|c|c|c|}
\hline $\begin{array}{c}\text { Independent } \\
\text { Variable }\end{array}$ & F(df) & $\mathbf{p}$ & $\mathbf{R}^{2}$ (Model) & $\mathbf{C}(\mathbf{p})$ \\
\hline SC1 & $\begin{array}{r}55.9060 \\
(1 ; 199)\end{array}$ & 0.0001 & 0.2202 & 40.1751 \\
Power & $\begin{array}{r}14.7688 \\
(2 ; 198)\end{array}$ & 0.0002 & 0.2746 & 25.7042 \\
\hline SC 3 & & & \\
\hline Likeability & $\begin{array}{r}12.3185 \\
(3 ; 197)\end{array}$ & 0.0006 & 0.3175 & 14.7124 \\
Internal & $\begin{array}{r}5.5773 \\
(4 ; 196)\end{array}$ & 0.0192 & 0.3364 & 10.9645 \\
\hline LC 2 & $\begin{array}{l}7.3026 \\
\text { External }\end{array}$ & 0.0075 & 0.3605 & 5.6741 \\
\hline JS 1 & $(5 ; 195)$ & & & \\
General & & & & \\
\hline
\end{tabular}

Dependent Variable: Jenkins 1: Achievement (Phamacists $\mathrm{N}=200$ )

\begin{tabular}{|c|c|c|c|c|}
\hline $\begin{array}{l}\text { Independent } \\
\text { Variable }\end{array}$ & $F(d f)$ & $\mathbf{p}$ & $\begin{array}{c}\mathbf{R}^{2} \\
\text { (Model) }\end{array}$ & $C(p)$ \\
\hline $\begin{array}{l}\text { CO } 1 \\
\text { Service }\end{array}$ & $\begin{array}{r}22.2977 \\
(1 ; 199)\end{array}$ & 0.0001 & 0.1012 & 72.2469 \\
\hline $\begin{array}{l}\mathrm{SC} 3 \\
\text { Likeability }\end{array}$ & $\begin{array}{l}15.6316 \\
(2 ; 198) \\
\end{array}$ & 0.0001 & 0.1673 & 54.5267 \\
\hline $\begin{array}{l}\text { SC } 2 \\
\text { Task } \\
\text { Accomplishment }\end{array}$ & $\begin{array}{r}21.4251 \\
(3 ; 197)\end{array}$ & 0.0001 & 0.2493 & 32.0369 \\
\hline $\begin{array}{l}\mathrm{SC} 1 \\
\text { Power }\end{array}$ & $\begin{array}{l}12.9012 \\
(4 ; 196)\end{array}$ & 0.0004 & 0.2959 & 20.1344 \\
\hline $\begin{array}{l}\mathrm{CO} 2 \\
\text { Job Security }\end{array}$ & $\begin{array}{r}5.5530 \\
(5 ; 195)\end{array}$ & 0.0194 & 0.3155 & 16.2869 \\
\hline Job Involvement & $\begin{array}{l}4.4256 \\
(6 ; 194)\end{array}$ & 0.0367 & 0.3309 & 13.7075 \\
\hline
\end{tabular}


Table 2 continued

Dependent Variable: Jenkins 2: Hard Driving/Competitive (Pharmacists $\mathrm{N}=200$ )

\begin{tabular}{|l|c|c|c|c|}
\hline $\begin{array}{c}\text { Independent } \\
\text { Variable }\end{array}$ & $\mathbf{F}(\mathbf{d f})$ & $\mathbf{p}$ & $\mathbf{R}^{2}$ (Model) & $\mathbf{C}(\mathbf{p})$ \\
\hline SC 1 & $\begin{array}{r}48.5268 \\
(1 ; 199)\end{array}$ & 0.0001 & 0.1968 & 10.9442 \\
Power & $\begin{array}{r}9.6390 \\
(2 ; 198)\end{array}$ & 0.0022 & 0.2343 & 3.2909 \\
\hline LC 2 & & & \\
\hline External & $\begin{array}{r}4.6391 \\
\text { JS 1 }\end{array}$ & 0.0325 & 0.2520 & 0.7292 \\
General & $(3 ; 197)$ & & & \\
\hline
\end{tabular}

Dependent Variable: Jenkins 3: Speed and Impatience (Pharmacists $\mathrm{N}=200$ )

\begin{tabular}{|l|l|l|l|l|}
\hline \multicolumn{1}{|c|}{$\begin{array}{c}\text { Independent } \\
\text { Variable }\end{array}$} & \multicolumn{1}{|c|}{$\mathbf{F}(\mathbf{d})$} & \multicolumn{1}{|c|}{$\mathbf{p}$} & $\mathbf{R}^{2}$ (Model) & $\mathbf{C}(\mathbf{p})$ \\
\hline $\begin{array}{l}\text { JS 3 } \\
\text { Supervision }\end{array}$ & $\begin{array}{l}4.3884 \\
(1 ; 199)\end{array}$ & 0.0375 & 0.0217 & 17.7645 \\
\hline $\begin{array}{l}\text { CO 2 } \\
\text { Job Security }\end{array}$ & $\begin{array}{l}4.5982 \\
(2 ; 198)\end{array}$ & 0.0332 & 0.0440 & 14.8888 \\
\hline
\end{tabular}

From Table 2 it can be seen that in the pharmacists sample, Global Type A could be predicted by four personality sub-scales and one organisational variable $(\mathrm{N}=200)$. Global Type A scale score had $36.5 \%$ common variance with the five predictor variables. The Jenkins factor 1 (Achievement) was predicted by five of the personality sub-scales and by Job Involvement yielding a common variance between the dependent variable and the predictors of $33.09 \%$. The second Jenkins factor (Hard Driving/Competitive) had $25.20 \%$ common variance with the three independent variables (two personality variables and one organisational factor) included in the predictor model. The model for predicting scores on Jenkins factor 3 (Speed and Impatience) included one personality subscale and one organisational variable. Only $4.4 \%$ common variance existed between the dependent variable and the predictors in this model.

Further Stepwise Multiple Regression Analyses were done on the pharmacists' responses. The total scores of the variables measured by means of personality and organisational variables were regressed on the Global Type A score for pharmacists. Only the variables on which a total score made theoretical sense were included as independent variables in this analysis. The results of this 
analysis with the independent variables in the order in which they entered the Multiple Regression Model are shown in Table 3.

Table 3 Results from Stepwise Multiple Regression Analysis of Total Scores on Global Jenkins Activity Survey Score as Dependent Variable for Pharmacists

Dependent Variable: Jenkins Global (Pharmacists $\mathrm{N}=200$ )

\begin{tabular}{|l|c|c|c|c|}
\hline $\begin{array}{c}\text { Independent } \\
\text { Variable }\end{array}$ & $\mathbf{F}(\mathbf{d}$ ) & $\boldsymbol{p}$ & $\mathbf{R}^{2}$ (Model) & $\mathbf{C}(\mathbf{p})$ \\
\hline Self-Concept & $\begin{array}{r}34.2358 \\
(1 ; 198)\end{array}$ & 0.001 & 0.1474 & 18.9702 \\
\hline Job Involvement & $\begin{array}{r}12.4053 \\
(2 ; 197)\end{array}$ & 0.0005 & 0.1979 & 8.2353 \\
\hline Job Satisfaction & $\begin{array}{r}5.1676 \\
(3.196)\end{array}$ & 0.0241 & 0.2185 & 5.0402 \\
\hline
\end{tabular}

As can be seen from Table 3, the prediction model for the Global Type A score included one personality variable and one organisational factor. This model yielded a total prediction of the variance in the dependent variable of $21.85 \%$.

Stepwise Multiple Regression Analysis was also done on the responses of the accountants sample $(\mathrm{N}=175)$ in order to predict the Type A Behaviour pattern global score and sub-scales scores as dependent variables, with the personality and organisational sub-scale scores as independent variables. The results are shown in Table 4.

Table 4 Results from Stepwise Multiple Regression Analysis of SubScale Scores on Jenkins Activity Survey Scores as Dependent Variable for Accountants

Dependent Variable: Jenkins Global (Accountants $N=175$ )

\begin{tabular}{|l|c|c|c|c|}
\hline Independent Variable & $\mathbf{F}(\mathbf{d f})$ & $p$ & $\mathbf{R}^{2}$ (Model) & $\mathbf{C}(\mathbf{p})$ \\
\hline LC I & 58.0951 & 0.0001 & 0.2514 & 44.9631 \\
Internal & $(1 ; 174)$ & & & \\
\hline ENT 1 & 14.2838 & 0.0002 & 0.3088 & 30.4035 \\
Economic Innovation & $(2 ; 173)$ & & & \\
\hline SC 1 & 6.7510 & 0.0102 & 0.3350 & 24.8302 \\
Power & $(3 ; 172)$ & & & \\
\hline
\end{tabular}


Table 4 continued

\begin{tabular}{|c|c|c|c|c|}
\hline Independent Variable & $F(d)$ & $p$ & $\mathbf{R}^{2}$ (Model) & $C(p)$ \\
\hline $\begin{array}{l}\mathrm{CO} 2 \\
\text { Achievernent/Personal } \\
\text { Control }\end{array}$ & $\begin{array}{r}6.4517 \\
(4 ; 171)\end{array}$ & 0.0120 & 0.3594 & 19.8162 \\
\hline $\begin{array}{l}\text { SC 3 } \\
\text { Likeability }\end{array}$ & $\begin{array}{r}5.1362 \\
(5 ; 170) \\
\end{array}$ & 0.0247 & 0.3783 & 16.3650 \\
\hline $\begin{array}{l}\text { SC } 2 \\
\text { Task Accomplish }\end{array}$ & $\begin{array}{r}6.6780 \\
(6 ; 169) \\
\end{array}$ & 0.0106 & 0.4020 & 11.5079 \\
\hline $\begin{array}{l}\text { LC } 2 \\
\text { External Locus of } \\
\text { Control }\end{array}$ & $\begin{array}{r}4.2336 \\
(7 ; 168)\end{array}$ & 0.0412 & 0.4168 & 9.2427 \\
\hline
\end{tabular}

Dependent Variable: Jenkins 1: Achievement (Accountants $N=175$ )

\begin{tabular}{|c|c|c|c|c|}
\hline Independent Variable & $F(d f)$ & $\boldsymbol{p}$ & $\mathbf{R}^{2}$ (Model) & $\mathbf{C}(\mathbf{p})$ \\
\hline $\begin{array}{l}\text { ENT } 1 \\
\text { Economic Innovation }\end{array}$ & $\begin{array}{r}40.1622 \\
(1 ; 174)\end{array}$ & 0.0001 & 0.1884 & 60.3247 \\
\hline $\begin{array}{l}\text { SC2 } \\
\text { Task Accomplishment }\end{array}$ & $\begin{array}{l}11.6814 \\
(2 ; 173)\end{array}$ & 0.0008 & 0.2400 & 47.6134 \\
\hline $\begin{array}{l}\text { SC 3 } \\
\text { Likeability }\end{array}$ & $\begin{array}{l}8.3018 \\
(3 ; 172) \\
\end{array}$ & 0.0045 & 0.2752 & 39.5840 \\
\hline $\begin{array}{l}\text { LC 1 } \\
\text { Internal Locus of } \\
\text { Control }\end{array}$ & $\begin{array}{r}7.1250 \\
(4 ; 171)\end{array}$ & 0.0083 & 0.3044 & 33.2740 \\
\hline $\begin{array}{l}\text { LC } 2 \\
\text { External Locus of } \\
\text { Control }\end{array}$ & $\begin{array}{r}10.4357 \\
(5 ; 170)\end{array}$ & 0.0015 & 0.3448 & 23.7427 \\
\hline $\begin{array}{l}\text { ENT } 2 \\
\text { Achievement/Personal } \\
\text { Control }\end{array}$ & $\begin{array}{r}5.0400 \\
(6 ; 169)\end{array}$ & 0.0261 & 0.3639 & 20.3036 \\
\hline $\begin{array}{l}\text { LC 3 } \\
\text { Vicissitudes }\end{array}$ & $\begin{array}{l}4.7791 \\
(7 ; 168) \\
\end{array}$ & 0.0302 & 0.33812 & 17.2595 \\
\hline $\begin{array}{l}\mathrm{SC} 1 \\
\text { Power }\end{array}$ & $\begin{array}{r}4.3546 \\
(8 ; 167)\end{array}$ & 0.0384 & 0.3974 & 14.7540 \\
\hline
\end{tabular}




\section{Table 4 continued}

Dependent Variable: Jenkins 2: Hard Driving/Competitive (Accountants N $=175$ )

\begin{tabular}{|l|c|c|c|c|}
\hline \multicolumn{1}{|c|}{$\begin{array}{c}\text { Independent } \\
\text { Variable }\end{array}$} & $\mathbf{F}(\mathbf{d})$ & $p$ & $\begin{array}{c}\mathbf{R}^{2} \\
(\mathbf{M o d e l})\end{array}$ & $\mathbf{C ( p )}$ \\
\hline SC 1 & 53.9297 & 0.0001 & 0.2376 & -0.7709 \\
Power & $(1 ; 174)$ & & & \\
\hline ENT 1 & $\begin{array}{c}3.9495 \\
(2 ; 173)\end{array}$ & 0.0485 & 0.2548 & -2.5921 \\
Economic Innovation & & & \\
\hline
\end{tabular}

Dependent Variable: Jenkins 3: Speed/Impatience (Accountants $N=175$ )

\begin{tabular}{|l|c|c|c|c|}
\hline $\begin{array}{c}\text { Independent } \\
\text { Variable }\end{array}$ & $\mathbf{F}(\mathbf{d f})$ & $\boldsymbol{p}$ & $\begin{array}{c}\mathbf{R}^{\mathbf{2}} \\
\text { (Model) }\end{array}$ & $\mathbf{C ( p )}$ \\
\hline CO 2 & 6.2983 & 0.0130 & 0.0351 & 7.6395 \\
Job Security & $(1 ; 174)$ & & & \\
\hline CO 3 & 4.9036 & 0.0281 & 0.0619 & 4.6878 \\
Entrepreneurship & $(2 ; 173)$ & & & \\
\hline
\end{tabular}

It is seen from Table 4 that in the case of Global Type A Behaviour, the prediction models included seven of the personality sub-scales, yielding a total prediction of $41.68 \%$ of the variance in the dependent variable. The model for predicting Jenkins factor 1 (Achievement) scores contained eight of the personality sub-scales, with a total prediction of $39.33 \%$ of the variance in the dependent variable. The models built to predict both the second and third Jenkins sub-scales (Hard-driving/Competitive and Speed Impatience respectively) each contained only two of the personality sub-scales with a common variance of $25.48 \%$ and $6.19 \%$ respectively with the dependent variable.

The total (scale) scores on the same variables as for pharmacists were regressed on the Global Type A scores of accountants. The results are summarised in Table 5 . 
Table 5 Results from Stepwise Multiple Regression Analysis of Total Scores on Global Jenkins Activity Survey Score as Dependent Variable for Accountants $(\mathrm{N}=175)$

Dependent Variable: Jenkins Global (Accountants $N=175$ )

\begin{tabular}{|l|c|c|c|c|}
\hline \multicolumn{1}{|c|}{$\begin{array}{c}\text { Independent } \\
\text { Variable }\end{array}$} & F(df) & $p$ & $\mathbf{R}^{2}$ (Model) & $\mathbf{C}(\mathbf{p})$ \\
\hline Self-Concept & $\begin{array}{r}54.92 \\
(1 ; 173)\end{array}$ & 0.0001 & 0.2410 & 23.4964 \\
\hline $\begin{array}{l}\text { Entrepreneurial } \\
\text { Attitude }\end{array}$ & $\begin{array}{r}14.32 \\
(2 ; 172)\end{array}$ & 0.0001 & 0.3176 & 5.8536 \\
\hline Job Involvement & $\begin{array}{r}4.64 \\
(3 ; 171)\end{array}$ & 0.0326 & 0.3356 & 3.2331 \\
\hline
\end{tabular}

It can be seen from Table 5 that the model to predict the Global Type A scale scores contained two of the personality scales scores plus one organisational variable. A common variance of $33.56 \%$ between the dependent variable and the predictors was found.

The Multiple Regression Analyses of which the results are presented in Table 5, seem to indicate that the two occupational groups possibly differed from each other in terms of the variables included in the present study. To investigate this possibility, Stepwise Discriminant Analyses were carried out. This procedure was preferred to the use of Analysis of Variance seeing that ANOVA is not robust against large samples.

A Stepwise Discriminant Analysis with occupational group (pharmacists vs. accountants) as dependent variable was firstly carried out. Scores on the subscales of the instruments for measuring Type A Behaviour, Locus of Control, Career Orientations, Job Involvement, Job Satisfaction, Self-Concept and Entrepreneurial Attitude served as independent variables. The Discriminant model was developed over five steps with General Job Satisfaction, Security Career Orientation, Entrepreneurial Career Orientation, Intrinsic Job Satisfaction, Job Involvement entering into the Discriminant model, in this order. The model yielded a Wilks' Lambda of $0.76(\mathrm{~F}(5 ; 369)=23.81, p=$ $0.0001)$. The classification obtained showed that $70 \%(\mathrm{~N}=140)$ of the pharmacists group were placed correctly. The corresponding figures placed correctly for the accountants were $72.6 \%$ and $N=127$. In total, $71.2 \%$ or 267 of the 375 participants were placed in the correct occupational group, with $28.8 \%$ or 108 of the total group placed in the incorrect occupational group. When a jackknifed classification was carried out $70 \%(\mathrm{~N}=140)$ of the pharmacists and 
$70.3 \%(\mathrm{~N}=123)$ of the accountants were placed in the correct occupational group. Using such a solution 263 of the 375 respondents were therefore placed in the right occupational group.

An attempt was also made to determine how well the members of the two occupational groups could be classified by means of the respondents' total scores on the scales measuring Type A Behaviour, Job Involvement, Job Satisfaction, Self-Concept and Entrepreneurial Attitude. The other scales were not included in this analysis, because scores on these variables did not make conceptual and statistical sense as potential predictors of membership of the two groups. A Stepwise Discriminant Analysis yielded a model into which only Job Satisfaction and Job Involvement (in this order) entered. Wilks' Lambda in this model had a value of $0.93(\mathrm{~F}(2 ; 372)=13.40, p=0.0001$. The model classified $55.5 \%$ or 111 of the pharmacists and 116 or $66.3 \%$ of the accountants correctly into their occupational groups. Of the total sample $(\mathrm{N}=375) 227(60.5 \%)$ were classified correctly into their occupational groups. When a jackknifed classification was carried out $110(55 \%)$ of the pharmacists and $116(66.3 \%)$ of the accountants were classified correctly. In this classification correct categorisation of $226(60.3 \%)$ of the respondents was therefore obtained.

\section{DISCUSSION}

The results obtained are placed into perspective by comparing the findings of the present analysis, in which responses of accountants and pharmacists were analysed separately, with that of the previous research by Van Wyk et al. (1999a), in which the members of the two professions were treated as one group for the purposes of the statistical analysis. The findings of the present study are related to results of previous studies found in the literature.

\section{The relationship between Global Type $A$ and Personality Factors}

The results of the present Multiple Regression Analyses regarding the prediction of global Type A scores and those of the study reported by Van Wyk et al. (1999a) are summarised in Table 6. 
Table 6 Summary of Significant Correlations Between Global Type A Scores and Personality Variable Sub-Scales Over Two Analyses.

\begin{tabular}{|l|c|c|c|c|c|c|}
\hline \multicolumn{1}{|c|}{ Variable } & \multicolumn{2}{c|}{ Total Sample } & \multicolumn{2}{c|}{ Pharmacists } & \multicolumn{2}{c|}{ Accountants } \\
\hline & $\mathbf{r}$ & $\mathrm{R}$ & $\mathbf{r}$ & $\mathbf{R}$ & $\mathbf{r}$ & $\mathrm{R}$ \\
\hline Locus of Control 1 & $0.47^{* * *}$ & $\mathrm{X}$ & $0.41^{* * *}$ & $\mathrm{X}$ & $0.50^{* * *}$ & $\mathrm{X}$ \\
\hline Locus of Control 2 & & $\mathrm{X}$ & & $\mathrm{X}$ & & $\mathrm{X}$ \\
\hline Locus of Control 3 & & & & & & \\
\hline Career Orient 1 & $0.38^{* * *}$ & & $0.30^{* * *}$ & & $0.45^{* * *}$ & \\
\hline Career Orient 2 & & & & & & $\mathrm{X}$ \\
\hline Career Orient 3 & $0.20^{* * *}$ & & & & $0.25^{* *}$ & \\
\hline Career Orient 4 & & & & & & \\
\hline Job Involvement & $0.29^{* * *}$ & $\mathrm{X}$ & $0.30^{* * *}$ & & $0.23^{* *}$ & \\
\hline Job Satisfaction 1 & $0.25^{* * *}$ & $\mathrm{X}$ & $0.26^{* * *}$ & $\mathrm{X}$ & $0.17^{*}$ & \\
\hline Job Satisfaction 2 & $0.19^{* *}$ & & $0.23^{* *}$ & & & \\
\hline Job Satisfaction 3 & & & & & & \\
\hline Self-Concept 1 & $0.49^{* * *}$ & $\mathrm{X}$ & $0.47^{* * *}$ & $\mathrm{X}$ & $0.49^{* * *}$ & $\mathrm{X}$ \\
\hline Self-Concept 2 & $0.26^{* * *}$ & $\mathrm{X}$ & $0.22^{* *}$ & & $0.35^{* * *}$ & $\mathrm{X}$ \\
\hline Self-Concept 3 & & $\mathrm{X}$ & & $\mathrm{X}$ & $0.15^{*}$ & $\mathrm{X}$ \\
\hline Ent. Attitude 1 & $0.44^{* * *}$ & & $0.36^{* * *}$ & & $0.49^{* * *}$ & $\mathrm{X}$ \\
\hline Ent. Attitude 2 & $0.31^{* * *}$ & $\mathrm{X}$ & $0.25^{* *}$ & & $0.40^{* * *}$ & \\
\hline Ent. Attitude 3 & $-0.23^{* * *}$ & & $-0.27^{* * *}$ & & & \\
\hline
\end{tabular}

${ }^{*} p<.05^{* *} p<.01 * * * p<.001$

$\mathrm{X}$ Variable entered into multiple regression model

Significant correlations between Global Type A and LC1, CO1, JI, SC1, SC2, ENT1 and ENT2 were found for both professions. In both professions the SelfConcept sub-scales of Power (SC1) and Likeability (SC3) and the Internal and External Locus of Control factors ( $\mathrm{LCl}$ and LC2) entered the Multiple Regression Model with Global Type A as dependent variable. It seems that both the Self-Concept and Locus of Control variables play an important role in the prediction of Global Type A Behaviour for both professions.

In the case of pharmacists, the General Job Satisfaction (JS1) variable also entered the prediction of the Global Type A model. The Global Type A prediction model in the case of accountants also contained Economic Innovation (ENT1), Achievement/Personal Control (CO2) and Task Accomplishment (SC2). 
Compared to the Multiple Regression of the previous study (Van Wyk et al, 1999a) of the analyses of the joint responses of the two professional groups, a more differentiated picture is obtained from the Multiple Regression Analysis of the responses of the two separate groups. The following sub-scales entered the Multiple Regression Model for the two groups when combined: SC1 LCl, SC3, LC2, ENT2 JS1, SC2, JOBNN. The pattern for the two separate professional groups is somewhat different as shown above.

The two groups were differentiated on the basis of their scores on two of the personality variables measured, that is, the Security Career Orientation and the Entrepreneurial Career Orientation and three of the organisational variables, that is, General Job Satisfaction, Intrinsic Job Satisfaction and Job Involvement.

\section{Global Type A and Locus of Control}

In previous studies, Global Type A correlated significantly with Internal Locus of Control (Volkmer \& Feather, 1991 and Morrison, 1997 common variance $13.7 \%$ and $5.8 \%$ respectively). The study by Gomez (1997) yielded a significant but low ( $3.5 \%$ common variance) relationship between Global Type $A$ and External Locus of Control. The findings of the present study support the view that perception of the source of control is related to Type A Behaviour (Glass, Snyder \& Hollis, 1974; Glass, 1977; Newton, 1989; Hinton, Rotheiler, Gemmel and Shewan, 1991; Lawler, Schmied, Armstead \& Lacy, 1991 and Clark and Miller, 1991).

\section{Global Type A and Career Orientation}

Van Wyk et al. (1999a) reported a significant correlation between global Type A scores and the Service and Entrepreneurial Career Orientations (common variance of respectively 14 and 4 percent), though none of the Career Orientations variables entered the Stepwise Multiple Regression Model built in that study. In the current analysis none of the Career Orientations variables entered the prediction model in the case of Pharmacists, but the Achievement/Personal Control Career Orientation (CO2) did so in the case of accountants. A previous study by Burke (1983) where Career Orientation correlated with the Global Type A score, is difficult to compare with this study, as the factorial structure of the measuring instruments used in this study differs considerably from that in other studies. 


\section{Global Type $A$ and Job Involvement}

Van Wyk et al. (1999a) found a 7,8\% common variance between Job Involvement and Type A Behaviour. This is in agreement with the findings of Chusmir and Hood (1986 \& 1988) which showed a significant relationship of respectively 5.3 and 12.3 per cent common variance between Global Type A and Job Involvement and Organisational commitment. Van Wyk et al. (1999a) further indicate that Job Involvement entered the Stepwise Multiple Regression Model in the prediction of Global Type A. In the separate analysis of the responses of the individuals in the two occupations, however, Job Involvement did not enter in the Stepwise Multiple Regression Model.

\section{Global Type A and Job Satisfaction}

Van Wyk et al. (1999a) found significant but low correlations between Type A Global and General Job Satisfaction (JS1) and Intrinsic Job Satisfaction (JS2), with common variances of respectively 6.3 and 3.6 per cent. A significant negative relationship is reported between Job Satisfaction and Global Type A in the studies of Chusmir and Hood (1998), Byme and Reinhart (1990), Gamble and Matteson (1992) as well as Byme and Reinhart (1994), with common variances varying between 1.21 and $4.41 \%$. Other research shows a significant positive relationship between Job Satisfaction and Global Type A (Bedeian, Mossholder \& Touliotos, 1990; Day \& Bedeian, 1991; Kushnir \& Melamed, 1991; Norden, 1995). The common variances in these studies varied between 0.64 and 3.61 per cent. Van Wyk (1998) reports a variety of studies that found no relationship between Type A global and Job Satisfaction.

In the Stepwise Multiple Regression Analysis carried out by Van Wyk et al. (1999a) General Job Satisfaction (JS1) entered the model obtained as predictor of Global Type A scores. In the separate analysis of the responses of the two occupational groups however, General Job Satisfaction only entered as predictor of Global Type A for pharmacists but not for accountants.

\section{Global Type A and Self-Concept}

Van Wyk et al. (1999a) found a significant relationship between Global Type A and Power (SC1) as well as with Task Accomplishment/Morality (SC2) with $24 \%$ and $6,8 \%$ common variance respectively. In the study by Van Wyk et al. (1999a), both the Task Accomplishment/Morality and Likeability sub-scales entered the Stepwise Multiple Regression Model with Global Type A as dependent variable. In the present study, both Power (SC1) and Likeability (SC3) entered the models based on the two separate groups as predictors of Global Type A. In the case of accountants, Task Accomplistment/Moral (SC2) 
entered additionally as predictor. In the study by Wolf et al. (1981) which showed a negative correlation between Self-Concept and Type A Behaviour, the conclusion is reached that Type As have a deep sense of insecurity due to a lack of an internalised standard of excellence which may lead to a low Self-Concept. Lobel (1988) reports Type As to have a significantly lower Self-Concept than Type Bs. It should be noted, however, that in the present study the three factors in the Self-Concept scale were all significantly positively correlated with Global type A.

\section{Global Type A and Entrepreneurial Attitude}

Van Wyk et al. (1999a) found a significant positive relationship between Global Type $A$ and Economic Innovation (ENT1), Achievement/Personal Control (ENT2) and a negative relationship with Self-Esteem (ENT3) indicating common variances of respectively $19.4,9.6$ and 5.3 per cent. In the study by Van Wyk et al. (1999a), only the AchievementPersonal Control (ENT2) subscale entered the Stepwise Regression Analysis. In the present study, Entrepreneurial Attitude sub-scales did not enter the Stepwise Regression model for pharmacists, but did so in the case of accountants (ENT1, Economic Innovation).

The relationship between Jenkins Factor 1 (Achievement) and personality and organisational variable Sub-Scales

The results of the present analyses regarding the prediction of Jenkins Factor One (Achievement) scores by means of personality variables, compared to the findings reported by Van Wyk et al. (1999a), are summarised in Table 7.

Table 7 Summary of Significant Correlations between Jenkins Factor One (Achievement) and Personality and Organisational Variable Sub-Scale Scores Over Two Analyses

\begin{tabular}{|l|l|c|c|c|c|c|}
\hline \multicolumn{1}{|c|}{ Variable } & \multicolumn{2}{c|}{ Total Sample } & \multicolumn{2}{c|}{ Pharmacists } & \multicolumn{2}{c|}{ Accountants } \\
\hline & $\mathbf{r}$ & $\mathbf{R}$ & $\mathbf{r}$ & $\mathbf{R}$ & $\mathbf{r}$ & $\mathbf{R}$ \\
\hline Locus of Control 1 & $0.34^{* * *}$ & $\mathrm{X}$ & $0.28^{* * *}$ & & $0.41^{* * *}$ & $\mathrm{X}$ \\
\hline Locus of Control 2 & & $\mathrm{X}$ & & & & $\mathrm{X}$ \\
\hline $\begin{array}{l}\text { Locus of Control 3 } \\
\text { Career Orient 1 }\end{array}$ & $0.36^{* * *}$ & & $0.32^{* * *}$ & $\mathrm{X}$ & $0.41^{* * *}$ & $\mathrm{X}$ \\
\hline Career Orient 2 & $0.15^{* *}$ & & $0.17^{*}$ & $\mathrm{X}$ & & \\
\hline Career Orient 3 & & & & & $0.03^{*}$ & \\
\hline Career Orient 4 & & & & & & \\
\hline Job Involvement & $0.27^{* * *}$ & $\mathrm{X}$ & $0.31^{* * *}$ & $\mathrm{X}$ & $0.23^{* *}$ & \\
\hline
\end{tabular}


Table 7 continued

\begin{tabular}{|l|c|c|c|c|c|c|}
\hline \multicolumn{1}{|c|}{ Variable } & \multicolumn{2}{c|}{ Total Sample } & \multicolumn{2}{c|}{ Pharmacists } & \multicolumn{2}{c|}{ Accountants } \\
\hline & r & R & r & R & r & R \\
\hline Job Satisfaction 3 & & & & & & \\
\hline Self-Concept 1 & $0.31^{* * *}$ & $\mathrm{X}$ & $0.29^{* * *}$ & $\mathrm{X}$ & $0.34^{* * *}$ & $\mathrm{X}$ \\
\hline Self-Concept 2 & $0.29^{* * *}$ & $\mathrm{X}$ & $0.29^{* *}$ & $\mathrm{X}$ & $0.34^{* * *}$ & $\mathrm{X}$ \\
\hline Self-Concept 3 & & $\mathrm{X}$ & $-0.20^{* *}$ & $\mathrm{X}$ & & $\mathrm{X}$ \\
\hline Ent. Attitude 1 & $0.34^{* * *}$ & & $\mathbf{0 . 2 5 ^ { * * }}$ & & $0.43^{* * *}$ & $\mathrm{X}$ \\
\hline Ent. Attitude 2 & $0.29^{* * *}$ & $\mathrm{X}$ & $\mathbf{0 . 1 8 ^ { * * }}$ & & $0.41^{* * *}$ & $\mathrm{X}$ \\
\hline Ent. Attitude 3 & & & $-0.16^{*}$ & & & \\
\hline
\end{tabular}

${ }^{*} p<.05^{* *} p<.01{ }^{* * *} p<.001$

$\mathrm{X}$ Variable entered into multiple regression model

\section{Type A Achievement and Locus of Control}

Van Wyk et al. (1999a) report a significant relationship between Achievement (JS1) and Internal Locus of Control with a $11.56 \%$ common variance between the variables. In the Stepwise Multiple Regression Model both Internal and External Locus of Control entered as predictors of Achievement. The relationship between Achievement Type A and Internal Locus of Control is confirmed by Furnham (1983), Volkmer and Feather (1991) and Spector and O'Connell (1994), reporting common variances of respectively 7.3, 22,1 and 3.2 per cent. In this analysis of the responses of the two occupational groups, Locus of Control variables did not enter into the Stepwise Multiple Regression Model with Achievement (JF1) as dependent variable for pharmacists, but all three Locus of Control sub-scales were included in the case of accountants.

\section{Type A Achievement and Career Orientations}

In the Van Wyk et al. (1999a) study, the Type A Achievement factor significantly correlated with the Career Orientations of Service and Job Security with common variances of respectively 13.0 and a low 2 per cent. In the Stepwise Multiple Regression Analysis of the same study, Service (CO1), Job Security (CO2) and Entrepreneurial (CO3) were included in the model predicting Type A Achievement. In the separate analysis of the responses of the two occupational groups in the current study, the Service (CO1) and Job Security (CO2) Career Orientations entered the prediction only in the case of pharmacists. None of these variables entered the prediction model in the case of accountants. 


\section{Type A Achievement and Job Involvement}

The Van Wyk et al. (1999a) study indicated a significant relationship between Achievement (JF1) and Job Involvement with 7.3 per cent common variance. Job Involvement did not enter the Stepwise Regression model with Achievement as dependent variable in the Van Wyk et al. (1999a) study, while in the present study it did so for pharmacists but not for accountants.

\section{Type A Achievement and Job Satisfaction}

Van Wyk et al. (1999a) report a significant relationship between Achievement (JF1) and General as well as Intrinsic Job Satisfaction, with low common variances of respectively $2.6 \%$ and $2.3 \%$. In the Stepwise Multiple Regression Analysis with Achievement as dependent variable, General Job Satisfaction entered as predictor. In the separate analysis of responses of the two occupational groups, General Job Satisfaction (JS1) entered the prediction model in the case of pharmacists but none of the Job Satisfaction sub-scales entered in the case of accountants. The conclusion can be drawn that Job Satisfaction could be a predictor of Type A Achievement, depending on the occupation of the individual. The relationship does not appear to be strong.

\section{Type A Achievement and Self-Concept}

Van Wyk et al. (1999a) report a significant relationship between Achievement (JF1) and Power (SC1) and Task Accomplishment/Morality (SC2) with a common variance of $9.7 \%$ and $8.4 \%$ respectively. In the Stepwise Multiple Regression Analysis done in that study with Achievement as dependent variable, both Task Accomplishment/Morality (SC2) and Likeability (SC3) entered the prediction. In the current analysis of the two separate professions, Likeability (SC3) and Task Accomplishment (SC2) entered in the case of both pharmacists and accountants. In addition, Power (SC1) entered in the case of accountants. Self-Concept variables therefore seem to be related to the Achievement dimension of Type A Behaviour.

\section{Type A Achievement and Entrepreneurial Attitude}

Van Wyk et al. (1999a) identified the following significant relationships between Achievement (JF1) and variables that are part of Entrepreneurial Attitude: Economic Innovation (ENT1); Achievement/Personal Control (ENT2) and Self-Esteem (ENT3) with common variances of respectively $11.6 \%, 8.4 \%$ and a low $1.2 \%$. In the Stepwise Multiple Regression Analysis carried out in that study with Achievement as dependent variable, Economic Innovation (ENT1) entered the prediction. With the separate analysis of the responses of 
the two occupational groups, Entrepreneurial Attitude variables did not enter as predictor in the case of pharmacists but Economic Innovation (ENT1) and Achievement/Personal Control (ENT2) did enter as predictors of Achievement in the case of accountants. Entrepreneurial Attitude as predictor seems to be occupationally specific to Type A Achievement scales.

The relationship between Jenkins Factor 2 (Hard Driving/Competitive) and Personality and Organisational variable sub-scales

The findings of the Van Wyk et al. (1999a) study and the analyses carried out in the present study, regarding the relationships between Jenkins Factor 2 (Hard Driving/Competitive) scores and personality and organisational variables, are summarised in Table 8.

Table 8 Summary of Significant Correlations Between Jenkins Factor Two (Hard Driving/Competitive) and Personality and organisational Variable Sub-Scale Scores Over Two Analyses

\begin{tabular}{|l|l|l|l|l|l|l|}
\hline \multicolumn{1}{|c|}{ Variable } & \multicolumn{2}{c|}{ Total Sample } & \multicolumn{2}{c|}{ Pharmacists } & \multicolumn{2}{c|}{ Accountants } \\
\hline & $\mathbf{r}$ & $\mathbf{R}$ & $\mathbf{r}$ & $\mathbf{R}$ & $\mathbf{r}$ & $\mathbf{R}$ \\
\hline Locus of Control 1 & $\mathbf{0 . 4 0 ^ { * * * }}$ & $\mathrm{X}$ & $0.38^{* * *}$ & & $0.38^{* * *}$ & \\
\hline Locus of Control 2 & $-0.21^{* * *}$ & & $-0.29^{* * *}$ & $\mathrm{X}$ & & \\
\hline Locus of Control 3 & & & & & & \\
\hline Career Orient 1 & $0.23^{* * *}$ & & $0.16^{*}$ & & $0.30^{* * *}$ & \\
\hline Career Orient 2 & $-0.18^{* *}$ & $\mathrm{X}$ & $-0.15^{*}$ & & & \\
\hline Career Orient 3 & $0.20^{* * *}$ & & $0.14^{*}$ & & $0.18^{*}$ & \\
\hline Career Orient 4 & & & & & & \\
\hline Job Involvement & $0.19^{* * *}$ & & $0.18^{* *}$ & & & \\
\hline Job Satisfaction 1 & $0.24^{* * *}$ & $\mathrm{X}$ & $0.28^{* * *}$ & $\mathrm{X}$ & & \\
\hline Job Satisfaction 2 & $0.15^{* *}$ & & $0.15^{*}$ & & $0.16^{*}$ & \\
\hline Job Satisfaction 3 & & & & & & \\
\hline Self-Concept 1 & $0.48^{* * *}$ & $\mathrm{X}$ & $0.44^{* * *}$ & $\mathrm{X}$ & $0.49^{* * *}$ & $\mathrm{X}$ \\
\hline Self-Concept 2 & $\mathbf{0 . 1 2 ^ { * * }}$ & & & & $0.21^{* *}$ & \\
\hline Self-Concept 3 & $0.16^{* * *}$ & & $0.15^{*}$ & & $0.24^{* *}$ & \\
\hline Ent. Attitude 1 & $0.35^{* * *}$ & & $0.28^{* * *}$ & & $0.38^{* * *}$ & $\mathrm{X}$ \\
\hline Ent. Attitude 2 & $0.21^{* * *}$ & & $0.23^{* *}$ & & $0.22^{* *}$ & \\
\hline Ent. Attitude 3 & $-0.32^{* * *}$ & & $-0.36^{* * *}$ & & $-0.22^{* *}$ & \\
\hline
\end{tabular}

${ }^{*} p<.05{ }^{* *} p<.01{ }^{* * *} p<.001$

$\mathrm{X}$ Variable entered into multiple regression model 


\section{Jenkins Hard Driving/Competitive and Locus of Control}

Van Wyk et al. (1999a) report a significant positive relationship between Internal Locus of Control (LC1) and Hard Driving/Competitive (JF2) with a 15.2 per cent common variance. A significant negative relationship was reported with External Locus of Control (LC2) with a low common variance of 4.0 per cent. Internal Locus of Control entered the Stepwise Regression Model with Hard Driving/Competitive as dependent variable. In the analysis in the present study External control (LC2) entered the prediction model in the case of pharmacists, while none of the Locus of Control scales entered in the case of accountants.

\section{Jenkins Hard Driving/Competitive and Career Orientations}

The Van Wyk et al. (1999a) study indicated weak but significant relationships with the Career Orientations of Service (CO1, $4.8 \%$ common variance), Job Security $(\mathrm{CO} 2,3.2 \%$ common variance), Entrepreneurial $(\mathrm{CO} 3,3.6 \%$ common variance). Only Job Security entered the Stepwise Multiple Regression Model as independent variable. In the analysis of the responses of the two separate occupational groups, none of the Career Orientation sub-scales entered the Stepwise Multiple Regression Model with Hard Driving/Competitive as dependent variable.

\section{Jenkins Hard Driving/Competitive and Job Involvement}

Van Wyk et al. (1999a) reported that Hard Driving/Competitive correlated with Job Involvement with a 3.6 per cent common variance, but this variable did not enter the Stepwise Multiple Regression Analysis Model as independent variable. In the current analysis with the separation of the two occupations Job Involvement also did not enter as a predictor of Hard Driving/Competitive as dependent variable. It did correlate significantly with Hard-Driving/ Competitive behaviour. But the relationship was not strong.

\section{Jenkins Hard Driving/Competitive and Job Satisfaction}

Van Wyk et al. (1999a) report low positive but significant relationships between Hard Driving/Competitive (JF1) and the Job Satisfaction sub-scales of General (JS1, 5.8\% common variance) and Internal Job Satisfaction (JS2, 2.3\% common variance). General Job Satisfaction entered the Stepwise Multiple Regression Model with Hard Driving/Competitive as dependent variable. In the current analysis of the responses of the two occupational groups, General Job Satisfaction (JS1) entered as predictor of Hard Driving/Competitive only in the case of pharmacists. 


\section{Jenkins Hard Driving/Competitive and Self-Concept}

Van Wyk et al. (1999a) report Hard Driving/Competitive to show a significant positive relationship with the Self concept scales of Power (SC1), Task Accomplishment/Morality (SC2) and Likeability (SC3) with common variances of respectively $22.1 \%, 1.7 \%$ and $2.6 \%$. With Hard Driving/Competitive as dependent variable only Power entered the Stepwise Multiple Regression model. The re-analysis of the responses of the responses of the two separate occupational groups showed Power (SCl) to enter the Stepwise Multiple Regression Analysis with Hard Driving/Competitive as dependent variable for both pharmacists and accountants. Power as a Self-Concept variable seems to be a strong and consistent predictor of Hard Driving/Competitive Type A Behaviour.

\section{Jenkins Hard Driving/Competitive and Entrepreneurial Attitude}

Van Wyk et al. (1999a) found that Entrepreneurial Attitude Orientation subscales that showed a significant positive relationship with Type A Hard Driving/ Competitive were Economic Innovation (ENT1) and Achievement/ Personal Control (ENT2) with a significant negative relationship with Self-Esteem (ENT3) yielding common variances of respectively 12.3, 4.4 and 9.6 per cent. The Stepwise Multiple Regression Analysis did not enter any of the Entrepreneurial Attitude Orientation sub-scales with Hard Driving/Competitive as dependent variable into the prediction model. In the present study the variable ENT1 (Economic Innovation) was included in the Multiple Regression Model fo: the prediction of Hard-Driving/Competitive behaviour in accountants.

\section{Speed and Impatience (JF3)}

The findings with regard to the prediction of Speed and Impatience (Type A sub-scale 3) are summarised in Table 9.

Table 9 Summary of Significant Correlations Between Jenkins Factor Three (Speed and Impatience) and Personality and Organisational Varlable Sub-Scale Scores Over Two Analyses

\begin{tabular}{|l|c|c|c|c|c|c|}
\hline \multicolumn{1}{|c|}{ Variable } & \multicolumn{2}{|c|}{ Total Sample } & \multicolumn{2}{c|}{ Pharmacists } & \multicolumn{2}{c|}{ Accountants } \\
\hline & $\mathbf{n}$ & $\mathbf{R}$ & $\mathbf{r}$ & $\mathbf{R}$ & $\mathbf{r}$ & $\mathbf{R}$ \\
\hline Locus of Control 1 & $0.11^{*}$ & & & & $0.15^{*}$ & \\
\hline Locus of Control 2 & & & & & & \\
\hline Locus of Control 3 & $0.13^{*}$ & $\mathrm{X}$ & $0.14^{*}$ & & & \\
\hline
\end{tabular}


Table 9 continued

\begin{tabular}{|c|c|c|c|c|c|c|}
\hline \multirow[t]{2}{*}{ Variable } & \multicolumn{2}{|c|}{ Total Sample } & \multicolumn{2}{|c|}{ Pharmacists } & \multicolumn{2}{|c|}{ Accountants } \\
\hline & $\mathbf{r}$ & $\mathbf{R}$ & $\mathbf{r}$ & $\mathbf{R}$ & $\mathbf{r}$ & $\mathbf{R}$ \\
\hline \multicolumn{7}{|l|}{ Career Orient 1} \\
\hline Career Orient 2 & & & & $\mathrm{X}$ & $0.19^{*}$ & $X$ \\
\hline Career Orient 3 & $0.18^{* * *}$ & $X$ & $0.15^{*}$ & & $0.17^{*}$ & $\mathrm{X}$ \\
\hline \multicolumn{7}{|l|}{ Career Orient 4} \\
\hline \multicolumn{7}{|l|}{ Job Involvement } \\
\hline \multicolumn{7}{|l|}{ Job Satisfaction 1} \\
\hline \multicolumn{7}{|l|}{ Job Satisfaction 2} \\
\hline Job Satisfaction 3 & $-0.12^{*}$ & & $-0.15^{*}$ & $\mathrm{X}$ & & \\
\hline Self-Concept 1 & $0.13^{*}$ & & & & & \\
\hline \multicolumn{7}{|l|}{ Self-Concept 2} \\
\hline \multicolumn{7}{|l|}{ Self-Concept 3} \\
\hline \multicolumn{7}{|l|}{ Ent. Attitude 1} \\
\hline \multicolumn{7}{|l|}{ Ent. Attitude 2} \\
\hline Ent. Attitude 3 & & & & & & \\
\hline
\end{tabular}

${ }^{*} p<.05^{* *} p<.01^{* * *} p<.001$

$\mathrm{X}$ Variable entered into multiple regression model

\section{Speed/Impatience and different variables}

In the Van Wyk et al. (1999a) analysis the Speed/Impatience sub-scale (JF3) showed only a few significant but low correlations with the different sub-scales (common variances in brackets): Internal Locus of Control $(\mathrm{LCl} ; 1.2 \%$ ), Vicissitudes of Life (LC3; 1.7\%), Entrepreneurial (CO3; 2.9\%), Supervision (JS3; 1.4\%), Power (SC1, 1.7\%). Only the Vicissitudes of Life (LC3) and Entrepreneurial (CO3) sub-scale entered as predictors of Speed/Impatience in the Stepwise Multiple Regression Analysis. The separate analysis of the responses of the two professional groups showed Speed/Impatience as dependent variable in the Stepwise Multiple Regression Analysis related to Supervision (JS3) and Job Security (CO2) as independent variables in the case of pharmacists and Job Security (CO2) and Entrepreneurship (CO3) in the case of accountants. Speed and Impatience was weakly predicted in all three cases.

\section{CONCLUSION}

In the present study $36.05 \%$ of the variance in the Global Type A scores of the pharmacists could be predicted by means of the scores on the measured personality variables. The corresponding figure for accountants is appreciably 
higher at $41.68 \%$. It therefore seems that at least some of the personality and organisational variables in the present study are related to global Type A Behaviour. It was previously concluded (Van Wyk, 1998) that the Type A construct should be seen as a leamed behavioural pattem, not a personality type. The results of the present study seem to indicate that personality variables are indeed involved in the behaviour pattern. The possibility that social environmental factors influence the development of both Type A Behaviour as well as the personality and organisational variables associated with this kind of behaviour, can therefore be hypothesised as the basis of a further study. From the results it is also clear that some of the dimensions of Type A Behaviour, as identified in this study, are quite clearly related to some of the personality and organisational variables included in the study. In the case of pharmacists, $33.09 \%$ of the variance in the scores on the Achievement Type A sub-scale could be predicted by means of personality and organisational variable subscales with the corresponding figure per accountants being $39.74 \%$. A numerically lower common variance of $25.20 \%$ between predictors and the Type A dimension Hard-Driving/Competitive was found for pharmacists with the corresponding figure for accountants being $25.49 \%$. The relationship between the third Type A dimension, Speed and Impatience, and predictor variables was less strong. In the case of pharmacists, the common variance amounted to only $4.40 \%$, the corresponding figure for accountants being $6.19 \%$. The Locus of Control and Self-Concept variables seem to be quite consistently related to Type A Behaviour variables, as was also observed by Van Wyk et al. (1999a).

The present study has contributed some more clarity with regard to the origins of Type A Behaviour and its various dimensions. Further work is obviously required, seeing that the present study included only two professional groups. These groups cannot be seen as representative of all professional or knowledge workers in the South African society. In this study data was gathered by means of questionnaire only. Some of the relationships found may therefore be the result of mono-method bias.

Future studies should aim to cover a wider spectrum of respondents. In the South African context, the inclusion of more individuals from the majority group of black people should make for potentially interesting comparisons with the present results and the results of comparable studies in other countries. 


\section{REFERENCES}

The complete list of references is available in: VAN WYK, R., BOSHOFF, A.B. and BESTER, C.L. (1999) "Correlates of Type A Behaviour among Professionals", South African Journal of Economic and Management Sciences, NS 2(2): 315-34.

1 VAN WYK, R, BOSHOFF, A.B. and BESTER, C.L. (1999a) "Correlates of Type A Behaviour among Professionals", South African Journal of Economic and Management Sciences, NS 2(2): 315-34.

2 VAN WYK, R, BOSHOFF, A.B. and OWEN, R. (1999b) "Factor Structure and Internal Validity of Psychometric Instruments Developed in the USA among Professionals in South Africa", South African Journal of Economic and Management Sciences, SS 1(November): S1-S72. 